\title{
College News
}

Compiled by Md. Aminul Haque Khan and Rukhsana Parvin

\section{CPD Programme}

Continuing professional development is the process of life-long learning in practice. It helps the medical professionals to keep them up-to-date to meet the needs of the patient and health care services and to improve their knowledge, skill and attitude.

In Enam Medical College total 8 seminars were held during the period of May to August 2014. Around 300 students, doctors and teachers attended each of these seminars.

\section{CME Programme}

To enhance communication skill in teaching and learning and efficiency of judgment of teachers, especially the freshly appointed teachers in the assessment in examinations and to improve medical teaching standard of teachers by refreshing knowledge, skill and attitude, continued medical education (CME) programmes are very much needed. It is also essential to make them oriented with the updating of education system, teaching and research methodology and to share experience and views of senior faculties. In these perspectives, Medical Education Unit of Enam Medical College is arranging monthly teaching and learning sessions for all teachers of the college. All the teachers of the college actively participate in these sessions.

\section{Participation and presentation in APAME Convention 2014 in Mongolia}

Dr. Md. Aminul Haque Khan, Professor \& Head, Department of Biochemistry, Enam Medical College, Savar, Dhaka and Editor-in-Chief, Journal of Enam Medical College attended the joint meeting of WHO Western Pacific Region Index Medicus (WPRIM), WHO Index Medicus for South-East Asia Region (IMSEAR) and Asia Pacific Association of Medical Journal Editors (APAME) held in Ulaanbaator, Mongolia on $15^{\text {th }}$ August, 2014. He also participated in the APAME Convention 2014 held in Palace of Independence, Ulaanbaator, Mongolia on $16^{\text {th }}$ and $17^{\text {th }}$ August 2014 and presented a paper titled 'Medical Journals and Ethics of Research' in the plenary session of the convention.

\section{Achievement}

Dr. Md. Aminul Haque Khan, Professor \& Head, Department of Biochemistry, Enam Medical College, Savar, Dhaka and Editor-in-Chief, Journal of Enam Medical College participated in the Asia Pacific Association of Medical Journal Editors (APAME) Convention 2014 held in Palace of Independence, Ulaanbaator, Mongolia on $16^{\text {th }}$ and $17^{\text {th }}$ August 2014. He has been selected a member of Ethics and Editorial Policy Committee of APAME. 